\title{
Employee Turnover Intention at a Historically Disadvantaged South African University
}

\author{
Patrick W. Bwowe \\ Senior Lecturer, \\ Faculty of Economics and Information Technology Systems, \\ Walter Sisulu University, South Africa
}

DOI: https://doi.org/10.36941/jesr-2020-0117

\begin{abstract}
This study was motivated by the desire to explore the nature and level of turnover intention at a historically disadvantaged university in South Africa. A sample of 40 participants namely: academics, support and technical staff from the selected institution were purposely identified to participate in the study. The study was mainly exploratory in nature and used quantitative and descriptive research techniques to assess and explain seven behavioural intention factors to leave or stay in the current organisation. In addition, the study investigated factors that are likely to influence employee turnover intention in organisations. Findings show high desirability of employees to leave their present job. It further indicates that the ease of movement is influenced by external factors like availability of job opportunities elsewhere. Lack of advancement opportunities, job insecurity, workload, job opportunities and inadequate salary and benefits are the most influencing factors of turnover intention. The study is significant in that it provides important information on employees' intent to leave. In addition, knowledge gained from it can be used to enhance understanding of factors that predict actual turnover and could also assist in controlling employees' avoidance behaviours.
\end{abstract}

Keywords: turnover intention, avoidance behaviours, embeddedness, networks, pull factors, push factors

\section{Introduction}

The term "historically disadvantaged universities" (HDUs) as used in this study emanates from the unequal historical relations that existed in South African Higher Education especially during apartheid era. This historically social and economic divide left the predominantly black and rural-based universities with limited financial resources and in many respects underdeveloped. One should note that the emergence roles and cultures of universities in the post-merger era reflect the white political, economic and cultural domination and this has led to the history of unequal relations of power that was perpetuated during colonial and Apartheid rule being replicated in contemporary South African higher education system (Badat, 1999 \& Reddy, 2004).

Due to the limited ownership and control over economic resources, historically disadvantaged universities find it difficult to attract and retain highly qualified academics and competent support staff. Where they are lucky to attract them, these employees are normally poached by other well financially established tertiary institutions or join other private organisations (HESA, 2011). In some cases, academics and other talented employees leave due to social conditions of the environment where some of these institutions are located. There are also, cases where institutions lack appropriate leadership and management skills to run the institutions and consequently some of them have in the past been placed under administration. This at times has contributed to employees' job dissatisfaction 
and stress, thus increasing the prospects of employee desire to leave. The paper studies behavioural turnover intentions to explain the nature and level of turnover at the selected university. It further assesses and discuss factors which are likely to have an impact on turnover intentions in organisations.

\section{Theoretical Framework}

This study can be placed within the theories of organisational equilibrium and embeddedness. The Organisational equilibrium theory specifies that employees' decisions to quit are influenced by the individual's perceptions about the desirability and ease of movement (March \& Simon,1958). The desirability of movement is influenced by internal factors (push factors) like job satisfaction, organisational commitment and organisational environment, while the ease of movement is influenced by external factors (pull factors) such as job market conditions and labour market mobility (De Cuyper et al., 2011; Park, 2015; Takawira et al., 2014). Based on March and Simon (1958) perspectives on the organisational equilibrium theory, Allen \& Griffiths (1999, p.531) cite the need for inducements or payments to be in equilibrium with employee contributions so as to ensure continued existence of the organisation. If, there is a disequilibrium, between the employees' inducements, payments or other benefits, the employee will start thinking about leaving the organisation. In addition, once there are factors that employees see as inducements to move to other organisations (pull factors), such as job opportunities elsewhere then the desirability of movement is also created and the prospects of the employee leaving his or her current job are enhanced.

Recent research has suggested other perspectives which could also provide rational explanations to this study's findings. For instance, sociological perspectives on networks and network structures such as embeddedness could assist to expand knowledge of employee turnover (Bargiel et al. 2009; Borgatti \& Halgin, 2011; and Vardaman et al. 2015). The embeddedness perspective has three critical aspects which may be crucial to provide a better understanding of the study's findings. These aspects are: connectedness of employees to their jobs, other people and activities, the fit with other aspects in their life space plus sacrifice, which is the cost, both physical and emotionally attached to one's exit from their current job (Mitchell, 2001).

\section{Literature Review}

Turnover is a multi-stage process which includes attitudinal decisions and behavioural components (Martin \& Roodt, 2008; Sager, Griffeth, \& Home 1998). Job-related attitudes and the organisational environment factors play a big role in the determination of turnover intention. In addition, sociological perspectives on networks and network structures such as embeddedness, structural equivalence, and relational position have also been noted in literature as having a big role in the determination of turnover intention (Bergiel, Nguyen \& Clenney; Bibi, Pangil, \& Johari, 2016; Borgatti \& Halgin, 2011; Vardaman et al., 2015).

Researchers have described turnover intention as employee's deliberate intent or willingness to leave an organisation (Kaur \& and Mohindru, 2013; Tett \& Meyer, 1993). The intention to stay or leave has been cited in literature as a proxy indicator for actual turnover behaviour (Park 2015). In other words, a high turnover intention rate is likely to result in high turnover. This makes it imperative that such rates should be monitored if organisations are to control high levels of turnover and other withdraw factors. While minimum turnover levels may be advantageous to the organisations in that they can create new talents and new ideas in an academic institution (Alzubi, 2017), high turnover rates can also adversely affect the organisations in terms of productivity, cost and quality (Holtom \& Burch, 2016; Ng'ethe et al, 2012). In adition, high turnover rates are disruptive and can also negatively impact on the image of academic institutions (Alzubi, 2017).

Turnover intention has been further cited to have an impact on the sustainability and quality of any academic institution. The research discourse on turnover intention to a certain degree shows the quality, intellectual and creative abilities and commitments of an institution's academic staff when 
compared to other organisations as a major factor in its sustainability. Hence as some researchers have concluded, a repository of the most specialised and skilled intellectuals is vital (Ainer, Subramaniam, \& Arokiasamy, 2018; Ng'ethe, Iravo, \& Namusonge 2012; Yimer, Nega, \& Ganfure, 2017). The fear though, is that if academic institutions are affected by high turnover, the likelihood of losing academics with the above mentioned attributes becomes a critical issue. Hence, understanding factors that predict actual turnover and controlling employees' avoidance behaviours, which otherwise could have led to ease of mobility from the institution becomes necessary (Yamazakia \& Petchdee, 2015).

It has also been observed that high turnover diminishes the sense of community continuity, and coherence (Jain, 2013) thus leading to morale erosion, commitment and loss to the institution and discontinuity in institution's research and educational programmes (Olsen, 1992). Jain (2013) further asserts that disruption of a program's continuity and planning as a result of turnover affects performance and consistency across a variety of indicators, including student achievement as measured by standardised tests. Tettey (2006) observes that departure of academics from universities further diminishes synergies that come with a group of academics working together and has an impact on the scope of knowledge production and dissemination. In a similar vein, turnover as observed by O'Keefe (2000) can be associated with hidden costs to the organisation such as skills' drain and poor morale among the remaining employees. Rosser (2004, pp. 291-292) cites some positive attributes of turnover intention. He ascertains that turnover can result in promotion opportunities as well as improved management through restructuring and re-organising of reporting lines and decision making processes. This as the researcher of this study observes, can only happen if organisations are able to keep it at a desirable rate and ensure that strategies are in place to keep it that way. To achieve this, universities need to constantly engage is surveys relating to withdraw behaviours and employee turnover intention and studies like this one become imperative.

\section{Statement of the Problem}

Ng'ethe et al., (2012) note the global huge turnover challenges in higher institutions, with Australia predicting about 20 ooo academic staff shortage in the next decade, if the retention crisis is not resolved. In South Africa a substantial number (between $5 \%$ and $18 \%$ ) of academics were noted to be leaving higher education institutions (Tettey, 2006). Recent studies have also indicated significant challenges encountered by South African Higher Education in retaining key and talented academic staff (HESA, 2011; Robyn, 2012). This problem puts enormous pressure to academic institutions to develop retention strategies of their employees. Currently not many studies have been done on turnover intention with specific reference to HDUs in South Africa. Accordingly, a study of this nature becomes a significant source of new knowledge that can assist these institutions to manage and become more aware of the nature and size of turnover problems, monitor the level of employees' intent to leave and understand factors that may cause or be associated with turnover intention. In addition, as literature states it, the intent or desire to leave, is the antecedent to turnover and may give an employee's own estimation of the probability that he/she will be resigning or quitting. A study like this one therefore, becomes of a great value to university policy makers and management and those associated with HR decisions, in that it may provide more understanding of factors that predict the actual turnover. Furthermore, it can provide important information and suggestions on how to manage employees' avoidance behaviours.

\section{Purpose of the Study}

The intention of this paper is to explain and provide understanding of the nature and levels of turnover intention at one of the historically disadvantaged universities in South Africa. The paper seeks to indicate and describe the factors that employees normally associate with turnover intention in organisations. It is anticipated that findings from this study will assist managers and policy makes in HDUs to have a better understanding of employee turnover related issues and employee withdraw behaviours and consequently enhance their turnover management strategies. 


\section{Research Questions}

1. What is the nature and level of turnover intention at the selected University?

2. Which factors determine or influence employees' intention to leave an organisation?

3. What recommendations can be implemented at HDUs to enhance the effective management of turnover intention in these academic institutions?

\section{Methodology}

A sample of 40 academics, support and technical staff were purposely selected from one historically disadvantaged university in South Africa to respond to questions that inquired about the behavioural turnover intentions among the employees and the factors they believe are likely to influence such intentions. The study was mainly exploratory in nature and used quantitative and descriptive research techniques to assess and explain seven behavioural intention factors to leave or stay in the current organisation. These included the following: I often think of quitting, look for new job in the next year, will leave as soon as possible, I could just be as well working elsewhere, will continue till new job is found, there is not much to be gained by staying and I have little loyalty to the organisation"

Furthermore, the study investigated and described factors that are likely to influence/ or be associated with employee turnover intention in organisations. Fourteen items were treated as single independent variables that could have an impact or be associated with the dependent variable; turnover intention.

A self-administered questionnaire was used as data collecting tool. The questionnaire was divided into 2 sections. Section 1 related to respondents' biographical data. Section 2 contained the contextual variables for the study which were divided into sub-sections A and B. Sub-section A included questionnaire items that were developed by the researcher using existing and evaluated questionnaire items from literature to assess the behavioural turnover intentions at the selected institution while subsection B included factors that are likely to influence turnover intention.

Reliability tests on items in both sub-sections returned Cronbach alphas of (o.836), and o.88o respectively. These were considered appropriate for resolving issues related to reliability and the degree of internal consistence among the items and thus ensured the reliability of the research instrument.

Participants received an informed consent form explaining objectives, nature and type of research being undertaken.

Analysis was conducted using the statistical package for social sciences(SPSS). Descriptive research techniques were used to present results using frequency tables and percentages.

\section{Results}

\subsection{Descriptive statistics: Biographical factors}

Table 1. Biographical factors: Descriptive statistics - Responses from Participants

\begin{tabular}{|l|l|c|c|}
\hline Variables & Categories & Frequency $(\mathrm{N}=40)$ & Valid \% \\
\hline \multirow{3}{*}{ To which department do you belong } & Academic staff & 24 & 60.0 \\
\cline { 2 - 4 } & Academic support & 14 & 35.0 \\
\cline { 2 - 4 } & Administration/technical staff & 2 & 5.0 \\
\hline \multirow{4}{*}{ Gender } & Male & 15 & 37.5 \\
\cline { 2 - 4 } & female & 25 & 62.5 \\
\hline \multirow{5}{*}{ Age (Years) } & Below 26 & 2 & 5.0 \\
\cline { 2 - 4 } & $26-35$ & 11 & 27.5 \\
\cline { 2 - 4 } & $36-45$ & 17 & 42.5 \\
\cline { 2 - 4 } & $46-55$ & 4 & 10.0 \\
\cline { 2 - 4 } & 56 and above & 6 & 15.0 \\
\hline
\end{tabular}




\begin{tabular}{|l|l|c|c|}
\hline Variables & Categories & Frequency $(\mathrm{N}=40)$ & Valid \% \\
\hline \multirow{4}{*}{ Ethnicity } & Black & 39 & 97.5 \\
\cline { 2 - 4 } & white & 1 & 2.5 \\
\hline \multirow{5}{*}{ Length of service in present job } & 1 year and below & 8 & 20.0 \\
\cline { 2 - 4 } & $\mathbf{2}-4$ & 10 & $\mathbf{2 5 . 0}$ \\
\cline { 2 - 4 } & $5-10$ & 13 & 32.5 \\
\cline { 2 - 4 } & 11 and above & 9 & 22.5 \\
\hline \multirow{5}{*}{ Highest qualification } & Diploma & 4 & 10.0 \\
\cline { 2 - 4 } & Degree & 17 & 42.5 \\
\cline { 2 - 4 } & Master's degree & 2 & 35.0 \\
\cline { 2 - 4 } & PhD & 3 & 5.0 \\
\cline { 2 - 4 } & Matric / any other & 18 & 7.5 \\
\hline \multirow{2}{*}{ Job status } & Permanent & $\mathbf{2 2}$ & 55.0 \\
\cline { 2 - 4 } & Contract & 55.0 \\
\hline
\end{tabular}

The majority of the respondents were academics (65\%) while, $32.5 \%$ belonged to the support staff, and $5 \%$ to the technical support. Gender proportion was highly skewed towards male representation. In regard to ethnicity, $97.5 \%$ of the respondents were of black ethnic background, which is a representation of the area where this university is located. On age, results indicate that most employees are from 36 to 55 years old and above. The study revealed that the largest number of this category were in the middle age bracket of 36 to 45 years. Only $32.5 \%$ were 26 years and below. Results show that most of the respondents were of fairly long standing stay in their present job ( $\geq 5$ years) with $32.5 \%$ having served five to ten years and $\mathbf{2 2 . 5} \%$ more than ten years in their current positions. Those that had served below 5 years were $25 \%$ (two to four years) and $20 \%$ (one year and below). On whether employees were permanently employed or working on contract basis, results show a slightly bigger percentage being employed on contract basis (55\%) and $45 \%$ being employed on a permanent basis. The majority of the respondents either had a degree (42.5\%) or a master's degree (35\%). Those with a diploma were $10 \%$, a PhD $5 \%$ and those with matric certificates and below were $7.5 \%$.

\subsection{Research Question 1}

What is the nature and level of turnover intention at the selected University?

Seven variables were used to measure turnover pattern and desirability of employees to leave or stay in their present job at the selected institution. They included the following: "I often think of quitting, lookfor new job in the next year, will leave as soon as possible, I could just be as well working elsewhere, will continue till new job is found, there is not much to be gained by staying and I have little loyalty to the organisation".

Table 2: Descriptive statistics: Behavioural intentions: responses from participants

\begin{tabular}{|l|c|c|c|c|c|c|c|c|}
\hline \multicolumn{7}{|l}{ VARIABLES: BEHAVIORAL INTENTIONS } \\
\hline N $=40$ & $\begin{array}{c}\text { Often think } \\
\text { of quitting }\end{array}$ & $\begin{array}{c}\text { Look for } \\
\text { new job in } \\
\text { the next } \\
\text { year }\end{array}$ & $\begin{array}{c}\text { Will } \\
\text { leave } \\
\text { ASAP }\end{array}$ & $\begin{array}{c}\text { Could just be as } \\
\text { well working } \\
\text { elsewhere }\end{array}$ & $\begin{array}{c}\text { Will continue } \\
\text { till new job is } \\
\text { available }\end{array}$ & $\begin{array}{c}\text { Not much to } \\
\text { be gained by } \\
\text { staying }\end{array}$ & $\begin{array}{c}\text { Little loyalty to } \\
\text { the } \\
\text { organisation }\end{array}$ \\
\hline \begin{tabular}{l|l|c|c|c|c|c|c|}
\hline Responses in Percentages \\
Disagree
\end{tabular} & 35.0 & 25.0 & 27.5 & 27.5 & 5.0 & 12.5 & 15.0 \\
\hline Disagree & 15.0 & 12.5 & 32.5 & 17.5 & 15.0 & 32.5 & 45.0 \\
\hline Neutral & 22.5 & 32.5 & 17.5 & 15.0 & 10.0 & 30.0 & 12.5 \\
\hline Agree & 22.5 & 15.0 & 12.5 & 17.5 & 42.5 & 10.0 & 17.5 \\
\hline $\begin{array}{l}\text { Strongly } \\
\text { agree }\end{array}$ & 5.0 & 15.0 & 10.0 & 22.5 & 27.5 & 15.0 & 10.0 \\
\hline
\end{tabular}


Results show that most respondents were neither ready to leave the organisation immediately (6o\%) nor thought of quitting their present job (50\%). Only $22.5 \%$ agreed that they would leave as soon as possible while $27.5 \%$ often thought of quitting. Asked whether they agree that there was not much to be gained by staying in their current organisations, majority of them did not (45\%) while only $25 \%$ agreed. On whether, they agree that they have little loyalty to the organisation, a large majority disagreed $(60 \%)$ and just a few $(27.5 \%)$ agreed to the statement. Majority of respondents also disagreed with the statement that they will look for a new job in the next year (37.5\%) while $30 \%$ agreed. Notable for this variable is the large number of the undecided (32.5\%) and a small difference between those who disagreed and those who did. This could probably mean that the idea of looking for a job sometime next year could be a viable alternative for many of the employees. Results, also indicate a small difference among those who disagreed with the statement that they could just be as well working elsewhere (45\%) and those who agreed (40\%), thus strengthening the previous view that some of the employees will be engaged in a job search in the near future. The statement 'will continue till new job is available' was cited by the largest number of the respondents $(70 \%)$ with just only $20 \%$ disagreeing and $10 \%$ being undecided. This indicates a high turnover desire among the employees to leave when a job opportunity elsewhere is found.

\subsection{Research Question 2}

Which factors determine or influence employees' intention to leave an organisation?

The paper used 14 factors normally associated with/or influence turnover intention to assess the extent respondents believe that such factors can influence their desire or intent to leave or stay in their present job and organisation.

Table 3: Responses from participants on factors influencing turnover intention

\begin{tabular}{|l|c|c|c|c|c|}
\hline $\begin{array}{l}\text { Frequency } \\
\text { No = 40 }\end{array}$ & $\begin{array}{c}\text { Very unlikely } \\
\text { Valid (\%) }\end{array}$ & $\begin{array}{c}\text { Unlikely } \\
\text { Valid (\%) }\end{array}$ & $\begin{array}{c}\text { Neutral } \\
\text { Valid (\%) }\end{array}$ & $\begin{array}{c}\text { Likely } \\
\text { alid (\%) }\end{array}$ & $\begin{array}{c}\text { Very likely } \\
\text { Valid (\%) }\end{array}$ \\
\hline Lack of resources & 2.5 & 15 & 15 & 35 & 32.5 \\
\hline Poor management & 12.5 & 7.5 & 22.5 & 45.0 & 12.5 \\
\hline Lack of advancement opportunities & 2.5 & 2.5 & 15.0 & 35.0 & 45.0 \\
\hline Lack of equity and fairness & 7.5 & 12.5 & 32.5 & 20.0 & 27.5 \\
\hline Inadequate salary and benefits & 10.0 & 10.0 & 17.5 & 30.0 & 32.5 \\
\hline Lack of autonomy & 17.5 & 22.5 & 22 & 17.5 & 20.5 \\
\hline Job insecurity & 10.0 & 7.5 & 10.0 & 22.5 & 50.0 \\
\hline Conflicting job roles & 35.0 & 15.0 & 15.0 & 27.5 & 7.5 \\
\hline Work overload & 2.5 & 15.0 & 15.0 & 30.0 & 37.5 \\
\hline Lack of recognition & 12.5 & 12.5 & 17.5 & 27.5 & 30 \\
\hline Family ties and relationships & 37.5 & 15.0 & 32.5 & 10 & 5 \\
\hline Job opportunities elsewhere & 2.5 & 10.0 & 20.0 & 25.0 & 42.5 \\
\hline Lack of good schools, hospitals and other amenities & 17.5 & 30.0 & 17.5 & 20.0 & 15.0 \\
\hline Poor quality of work life & 15.0 & 20.0 & 22.5 & 20.0 & 22.5 \\
\hline
\end{tabular}

More than fifty percent of the respondents cited the following factors as likely influencers of turnover intention: lack of advancement opportunities (80\%), job insecurity (72.5\%), job opportunities elsewhere $(67.5 \%)$, work overload $(67.5 \%)$, lack of resources $(67.5 \%)$, poor management $(67.5 \%)$, inadequate salary and benefits $(62.5 \%)$ and lack of recognition $(57.5 \%)$. Other factors which were cited as likely influencers but with less than $50 \%$ majority of the respondent were; poor quality of work life (42.5\%) and lack of equity and fairness (47.5\%). Surprisingly, two factors: Lack of good schools, hospitals and other amenities $(47.5 \%)$ and family ties and relationships $(52.5 \%)$ were cited by a slightly 
larger percentages as unlikely factors to influence turnover intention. Other factors cited by majority of respondents as unlikely factors to influence turnover intention are conflicting job roles $(50 \%)$ and lack of autonomy (40\%).

\section{Discussion of Findings}

\subsection{Level and nature of turnover intention at the selected university.}

The study revealed that majority of employees would quit the institution if a new job is found. However, one distinctive finding of the study is that the propensity to change company or the desire to quit is more influenced by the external factor, namely, the availability of job opportunities elsewhere than push factors such as job satisfaction or organisational commitment. This is evidenced by the large number of the employees at the selected institution $(70 \%)$ who were found to have a strong intention to quit and to a certain degree think of leaving the organisation if a job opportunity was found elsewhere. These results confirm other research findings which ascertain that the availability of alternative jobs or external factors such as job market conditions and labour market mobility can influence the ease of movement of employees from their current jobs (De Cuyper et al., 2011; Kalayu, Meaza, \& Abebe 2020; Takawira et al., 2012). Moreover, Stahl et al, 2009 observes that perceived career opportunities outside the organisation increase the employee's intentions to leave the organisation while, (Simon \& Won, 2017) found low career alternatives as a pull factor which is a statistically significant predictors of turnover intention.

The study also reveals that most employees in the organisation are neither ready to leave the organisation immediately nor often think of quitting their present job. Furthermore, findings indicate that they still believe that it is still worthy to stay and equally so most of them don't believe that they are not committed to the organisation. These findings may seem to be contradictory in some cases because, while the largest number of employee indicate their desire to leave the organisation once job opportunities are available elsewhere, on the other hand, the majority don't seem to be desiring to quit immediately or accepting that it is no longer worthy to continue working for the organisation. Indirectly, from this study's results one may speculate that the explanations for these findings lie in more recent research which has suggested that social networks or webs of relationships as other perspectives that could assist in explaining turnover intention in organisations (Bartunek, Huang, \& Walsh, 2008; Bibi et al., 2016; Felps et al., 2009; Mossholder et al., 2005; Vardaman et al., 2015). Research has cited the need to consider Sociological perspectives on networks and network structures such as embeddedness, structural equivalence, and relational position as factors that can expand knowledge of employee turnover (Feeley 2000; Mossholder et al. 2005 and Vardaman et al., 2015).

It is argued that relational webs of attachments to social networks and network structures may tie individuals to organisations and create a sense of "stuckness" (Mitchell, 20o1). Hence an employee that may harbor the intention to quit may not find it easy to make an immediate decision to move knowing that there might be sacrifices associated with quitting. Hence, irrespective of whether the employee is dissatisfied with the job or not committed to the organisation and therefore think of leaving, such employee may be entangled in a web of network relationships that it may not be easy for him/her to make an immediate decision about when to quit.

\subsection{Factors determining or influencing employees' intention to leave an organisation}

Findings show that all the fourteen factors investigated in this study have an impact or influence on turnover intention. However, factors which have the biggest effect on turnover intention according to their order of importance are: lack of advancement opportunities $(80 \%)$, job insecurity $(72.5 \%)$, job opportunities elsewhere $(67.5 \%)$, workload $(67.5 \%)$, lack of resources $(67.5 \%)$, poor management (67.5), inadequate salary and benefits $(62.5 \%)$ poor management (67.5), inadequate salary and benefits $(62.5 \%)$ and lack of recognition (57.5\%). Other factors that were also cited below $50 \%$ by majority of 
the respondents as likely influencers of turnover intention are poor quality of work life $42.5 \%$ and lack of equity and fairness $47.5 \%$.

These results are replicated in most research findings on turnover intention. Stahl et al (2009) ascertains that lack of career advancement opportunities inside the organisation increase the employee's intentions to leave. Theron, Barrkhuizen, and Du Plessis, (2015) identify uncompetitive remuneration packages, lack of incentives and unfair promotional policies as some of the reasons for high turnover in South African Higher institutions. This augurs well with the study findings that cite inadequate salary and benefits, lack of advancement opportunities and lack of equity and fairness as some of the most influencing factors of turnover intention. In a similar vein, Ergado and Gojeh (2015) and Long et al., (2017) concur with the study's findings on lack of equity and fairness when they assert that a perceived unfair compensation system, with poor salary and incentives plus unfair or unequal treatment can result in turnover intention.

The Council for Higher Education (CHE, 2008) and Higher Education South Africa (HESA 2011) agree that compensation is a key reason for the academics to leave higher educational institutions (HEIs). HESA further notes that salary differentials between the private sector and HEIs are sizable and growing thus making those with uncompetitive remuneration packages such as academics to be poached by the private sector organisations.

The study shows job insecurity as being cited as the second most important factor that influence turnover intention. These findings confirm Heryanda (2019) findings which indicate that job insecurity has a negative and significant influence on job satisfaction and further more a positive and significant impact on turnover intention. In other findings the paper is in agreement with researchers like (Bitzer, 2008; DeVillier \& Steyn, 2009) who assert that student numbers result in heavy work overloads which ultimately result in higher turnover rates in South African higher institutions of learning. Lack of resources and poor management are also cited by majority of respondents in this paper's findings as factors influencing turnover intention. These finding give credence to Ladelsky and Catana (2013) observations, which postulates human resource management issues and leadership styles as among the causes of turnover intention.

Finding on lack of good schools, hospitals and other amenities and lack of autonomy show that the difference between those respondents who agreed and those who did not agree that these factors influence turnover intention was relatively small and in addition, there was also a big number of those that were undecided meaning that these results could not be conclusive. Further studies of these factors are therefore necessary in HDUs.

\section{Practical Implications}

Findings of this study are aimed at making managers and policy makers at HDUs aware of the increasing turnover problems at higher institution of learning and the impact it will have on the future sustainability of higher education both in terms of management and retention of qualified academics at these institutions. For these universities to stay on top of their game, they will need to constantly engage is surveys relating to withdraw behaviours and employee turnover intention. These surveys will enable them to become more aware of the nature and size of turnover problems in order to monitor effectively the level of employees' intent to leave and also understand factors that may cause or be associated with turnover intention. In addition, constant policy reviews and evaluation of employee turnover strategies on withdraw behaviour will have to be maintained to ensure that managers are ahead in their awareness and understanding of turnover problems at their institutions.

\section{Conclusion}

The study has clearly indicated a high desire for quitting among employees at the institution and to some extent a desire to leave in a near future. Results have also demonstrated that while employees can harbour the thought of quitting, the decision to act on it is a difficult one to make. In addition to 
perceived job attitudes such as job satisfaction and organisational commitment, factors like organisational culture, personal values, career aspirations and social networks can have a big influence on employees' decision to quit.

\section{Recommendations}

Strategies at institution of higher learning, especially the HDUs should seek to maintain a balance between job attitudes and embeddedness factors. The degree of employee's job embeddedness towards the professional and social environment or networks may determine the nature and the level of turnover intention and the real timing of the intention to quit. Employees may feel fully integrated in their professional and social environment that they may not want to lose or sacrifice those links for the unknown job or the unfamiliar environment (Ngo-Henha, 2017; Vardaman et al., 2015). This kind scenario must be understood by managers at these institutions to enable them become more inclusive in their thinking and understanding of factors that may lead to turnover intention.

The author further recommends that reward systems at these universities should be comprehensive, equitable and fair and should promote justice and fairness to all employees and command high employee satisfaction, loyalty and employee commitment (Bwowe \& Marongwe, 2018). These kind of rewards will prevent the movement of highly skilled talents from universities to other organisations.

Also, HDUs should ensure that these pay systems are performance-based and are embedded with employee recognition to ensure attraction of highly skilled academics and support staff.

The researcher further recommends that due diligence be placed on establishing strategies that can assist to forestall the antecedents to quit and withdraw behaviour amongst the newly recruited and Generation Y academics as this will ensure quality and sustainability of South African Higher Education (Martin \& Roodt, 2008) especially during this period of $4^{\text {th }}$ Industrial Revolution. The author believes that while the elderly employees may be entangled in a web of social networks in and around their working environment the young and the newly employed could be more interested in careers and avenues that are more innovative and challenging. Hence any chance of availability of such opportunities elsewhere could be more appealing and they may not hesitate to make quick decisions on quitting.

\section{Limitations and Opportunities for Further Research}

A number potential limitations to this study should be noted. First, the size of the sample for this study may be small and could restrict generalisation to a certain extent. Hence future research is needed with larger samples and with more coverage of the HDUs. In addition, many of these HDUs have just gone through a merger process, hence future researchers should consider employing longitudinal studies in order to assess turnover patterns over time. In addition, separate research studies both for academics and support staff could yield different findings and researchers are encouraged to undertake them in future.

Finally, other areas of interest recommended for further study could include among others, the mediating effect of factors like social networks, location of the institutions, organisational culture and leadership, job role and stress and family relationships on turnover intentions.

\section{References}

Ainer, C.D., Subramaniam. C., Arokiasamy, L. (2018). Determinants of Turnover Intention in the Private Universities in Malaysia: A conceptual paper: SHS Web of Conferences 56, 03004. https://doi.org/10.1051/shsconf/20185603004 ICLM 2018

Allen, D.G., \& Griffeth, R.W. (1999). Job performance and turnover: A review and integrative multi-route model. Human Resource Management Review, 9(4), 525-548. 
Alzubi, Y.Z.W. (2017). Turnover intentions in Jordanian universities: The role of leadership behaviour, organisational commitment and organisational culture. International Journal of Advanced and Applied Sciences, 5(1), 177-192.

Badat, S. (1998). Higher Education: The Historically Disadvantaged Institutions. Briefing Paper. EPU UWC/oo53.

Bartunek, J.M., Huang, Z., \& Walsh, I.J. (2008). The development of a process model of collective turnover. Human Relations, 61(1), 5-38. DOI: http://10.1177/0018726707085944

Bergiel, E. B., Nguyen, V. Q., Clenney, B. F., et al. (2009), Human resource practices, job embeddedness and intention to quit. Management Research News, 32(3), 205-219.

Bibi. P., Pangil, F.B., \& Johari, J.B. (2016). HRM practices and employees' retention: The Perspective of Job Embeddedness Theory. Asian Journal of Multidisciplinary, 4(5), 4.

Bitzer, E.M. (2008). The professoriate in South Africa: Potentially risking status inflation. South African Journal of Higher Education, 22, 265-281.

Borgatti, S.P., Brass, D.J., \& Halgin, D.S. (2014), Social Network Research: Confusions, Criticisms and Controversies, Contemporary Perspectives on Organizational Social Networks. Research in the Sociology of Organizations, 40, 1-29. https://doi.org/10.1108/So733-558X(2014)ooooo40001

Bwowe, P., \& Marongwe, N. (2018). Implementing a total reward strategy in selected South African municipal organisations. SA Journal of Human Resource Management, 16. doi:https://doi.org/10.4102/sajhrm.v16io.927

Council on Higher Education (CHE). (2008). The state of higher education in South Africa. Higher Education Monitor No. 8. Pretoria: Council on Higher Education.

De Cuyper, N., Van der Heijden, B., \& De Witte, H. (2011). Associations between perceived employability, employee well-being, and its contributions to organizational success: A matter of psychological contract. The International Journal of Human Resource Management, 22 (7). DOI: https://doi.org/10.1080/09585192.2011.561962

De Villiers, A.P., \& Steyn, A.G.W. (2009). Effect of changes in state funding of higher education output in South Africa: 1986-2007. South African Journal of Higher Education, 22, 43-6.

Erasmus, B.J., Grobler, A., \& Van Niekerk, M. (2015). Employee retention in a higher education institution: An organisational development perspective. Progressio, 37(2), 32-62.

Ergado, A.A., \& Gojeh, L.A. (2015). Contributory factors to library staff turnover pattern and retention in academic libraries of public and private universities in Ethiopia. International Journal of Library Science, 4 (4), 81- 90

Feeley, T.H., Hwang, J., \& Barnett, G.A. (2008) Predicting employee turnover from friendship networks. Journal of Applied Communication Research, 36(1), 56-73.

Felps, W., Mitchell, T.R., Hekman, D.R., Lee, T.W., Holtom, B.C., \& Harman, W.S. (20o9) Turnover contagion: How coworkers' job embeddedness and job search behaviours influence quitting. Academy Management Journal, 52(3), 545-561.

Guha, H., \& Chakrabarti, S. (2016). Differentials in attitude and employee turnover propensity: A study of information technology professionals. Global Business and Management Research: An International Journal, 8(1).

Hailemichael, M., \& Gezahegn, M. (2018). Determinants of turnover intention of employees mong the academic staffs: The case of some selected Ethiopian Universities. Journal of Economics and Sustainable Development, 9(15).

Heryanda, K.K. (2019) The effect of Job Insecurity on turnover intention through work satisfaction in employees of Pt Telkom Access Singaraja. International Journal of Social Science and Business, 3 (3) 98-205. https://ejournal.undiksha.ac.id/index.php/IJSSB/index

HESA. (2011). A generation of growth: Proposal for a national programme to develop the next generation of academics for South African higher education. Pretoria: University of South Africa.

Holtom, B.C., \& Burch, T.C. (2016). A model of turnover-based disruption in customer services. Human Resource Management Review, 26(1), 25-36.

Idiegbeyan-ose, J., Opeke, R., Nwokeoma, M., \& Sisulu, I. (2018). Influence of organisational culture on turnover intention of library university staff in private libraries, South-West Nigeria. Academy of Strategic Management Journal, $17(4)$.

Iyigun, O., \& Tamer, I. (2012). The impact of perceived organizational justice on turnover intention: Evidence from an international electronic chain store operating in turkey. Journal of Global Strategic Management, 6(1), 5-16. http://dx.doi.org/10.2046o/JGSM.2012615782

Jain, S. (2013). The causes of turnover intention in the employee of educational institutes: An observation. Tactful Management Research Journal, 1(7).

Kalayu, H., Meaza, B., \& Abebe, M. (2020). The pattern, intent and causes of employees' turnover in Debreberhan University. Journal of Human Resource Management, 8(1), 21-31. https://doi.org/10.11648/j.jhrm.2020o801.14

Kaur, B., \& Mohindru, P.D. (2013) Antecedents of turnover intentions: A literature review. Global Journal of Management and Business Studies, 3(10), 1219-1230.

Ladelsky, K.L., \& Catana, G.A. (2013). Causes affecting voluntary turnover in IT sector. Review of some empirical studies. Marketing from Information to Decision, 6, 102-113. 
Long, C.S., Azami, A., Kowang, T.O., \& Fei, G.O. (2016). An analysis on the relationship between work family conflict and turnover intention: A case study in a manufacturing company in Malaysia. International Business Management, $10(3), 176-182$.

March, J.G., \& Simon, H.A. (1958) Organizations. New York: John Wiley \& Sons.

Martin, A., \& Roodt, G. (2008). Perceptions of organizational commitment, job satisfaction and turnover intentions in a post-merger South African tertiary institution. South African Journal of Industrial Psychology, 34(1), 23-31

Mitchell, T. R. (2001) Why people stay: using job embeddedness to predict voluntary turnover. Academy of management journal, 44, 1102-1122

Mossholder, K.W., Settoon, R.P., \& Henagan, S.C. (2005) A relational perspective on turnover: Examining structural, attitudinal, and behavioral predictors. Academy Management Journal, 48(4), 6o7-618.

Ng'ethe, J.M., Iravo, M.E., \& Namusonge, G.S. (2012). Determinants of Academic Staff Retention in Public Universities in Kenya: Empirical Review. International Journal of Humanities and Social Science, 2(13), $205-212$.

Ngo-Henha, P.E. (2017). A review of existing turnover intention theories. International scholarly and scientific research, $11(11), 2760-2767$.

O'Keefe, T. (200o). Lost employee costs more than just a pay check. Atlantic Business Chronicle. Retrieved from: http://www.bizjournals.com/atlanta/stories/200o/o1/24/smallb7.html?page=all

Olsen, D. (1992). Interviews with faculty: Why do they leave? In D.H. Wulff \& J.D. Nyquist (Eds.), To improve the academy: Research for faculty, instructional, and organisational development. Stillwater, OK: New Forums Press.

Park, J. (2015). Determinant of turnover intent in higher education. The case of international and US faculty. Virginia Common Wealth University.

Phayoonpun, T., \& Mat, N. (2014). Organizational justice and turnover intention: The mediation role of job satisfaction. International Post Graduate Business Journal, 6 (2), 1-21.

Reddy, T. (2004). Higher education and social transformation South Africa case. Council on Higher Education, Pretoria: CHE (SA).

Robyn, A., \& Du Preez, R. (2013). Intention to Quit among generation Y academics in higher education. South African Journal of Industrial Psychology, 31(1). Http://dx.do.org/10.4102/sajip.v39:1.1106

Rosser, V. J. (2004). Faculty members' intentions to leave: A national study on their worklife and satisfaction. Research in Higher Education, 45(3), 285-309.

Ryan, J.F., Healy, R., \& Sullivan., J. (2012). Oh, won't you stay? Predictors of faculty intent to leave a public research university. Higher Education, 63(4), 421-437.

Sager, J.K., Griffeth, R.W., \& Hom, P.W. (1998). A comparison of structural models representing turnover cognitions. Journal of Vocational Behaviour, 53(2), 254-273.

Shahzad, M. B. (2016). Impact of perceived job autonomy on turnover intention in sales \& marketing managers of services industry: Moderating role of procedural and distributive justice. Science International, 28(3), $2881-2886$.

Simon, M., Pack, S.M., \& Won, D. (2017) From push to pull: factors influencing turnover decisions of middle-level athletic administrators. Journal of Physical Education and Sport, 17, 117-121.

Stahl, G.K., Caligiuri, P., Cerdin, J., \& Taniguchi, M. (2009). Predictors of turnover intentions in learning-driven and demand driven international assignments: The role of repatriation concerns, satisfaction with company support, and perceived career advancement opportunities. Human Resource Management, 48(1), 91-111.

Takawira, N., Coetzee, M., \& Schreuder, D. (2014). Job embeddedness, work engagement and turnover intention of staff in a higher education institution: An exploratory study. SA Journal of Human Resource Management, 12 (1). http://dx.doi.org/10.4102/sajhrm.v12i1.524

Tettey, J.W. (2006). Staff retention in African Universities: Elements of a Sustainable strategy. Washington, DC: World Bank

Theron, M., Barrkhuizen, N., \& Du Plessis, Y. (2014) Managing the academic talent void: Investigating factors in academic turnover and retention in South Africa. South African Journal of Industrial Psychology, 40(1). http://dx.doi.org/10.4102/sajip.v40il.1117

Vardaman, J.M., Taylor, S., Alan, S., Gondo, M.B., \& Amis, J. (2015). Translating intention to behaviour: The interaction of network structure and behavioural intentions in understanding employee turnover. Organisation Science, 26(4), 1177-1191.

Yamazakia, Y., \& Petchedee, S. (2015). Turnover intention, organisational commitment and specific job satisfaction among production employees in Thailand. Journal of Business and Management, 4(4) 22-38.

Yimer, I., Nega, R., \& Ganfure, G. (2017). Academic staff turnover Intention in Madda Walabu University, Bale Zone, South-east Ethiopia. International Journal of Higher Education, 6(3). https://doi.org/10.5430/ijhe.v6n3p21 